\title{
The Impact of Loyalty Cards in Retaining Customers: A Study with reference to Mega Mart Retail Outlet in Mangalore city.
}

\section{* Prof.Deepak Rao \\ ** Prof. Rashmitha R. Kotian}

\section{Abstract}

Fierce competition and complexity of modern business has prompted organizations to strive for creative and innovating strategies to retain customers. As attracting new customers in the business is far more costly than retaining existing customers; business organizations have started offering lucrative loyalty programmes to retain existing customers. The current study is empirical research that focuses on the effect of loyalty programs on customer retention with reference to Mega Mart Retail outlet. The data for the study was collected from Mangalore region from the customers who physically visited Mega Mart retail outlet for buying their products. The results indicated that loyalty card programme has resulted in an increase in their purchases from the outlet and customers use loyalty cards most of the time while making their purchases.

Keywords: Loyalty card, Customer Retention, Customer Loyalty, Retail outlet

\section{Introduction}

"Good customers are an asset which, when well managed and served, will return a handsome lifetime income stream for the company."

Philip Kotler

In recent times, retailers are being exposed to a new generation of customers. These new generation customers can be classified on the basis of individual differences in expectations, preferences for wider choice, extent of brand loyalty and willingness to try competing brands so as to perceive higher value satisfaction. The changing

\footnotetext{
* Assistant Professor, A.JInstitute of Management, Mangalore **Assistant Professor, A.JInstitute of Management, Mangalore
} 
profile of Indian consumer is likely to change the shape of Indian consumer market permanently. To match the varying consumer tastes and preferences, retailers have adopted innovative strategies. This tendency has resulted in issuing of loyalty cards to the customers as a means of innovative strategy to retain the customers.

As an important component of firms' customer relationship management (CRM) strategy, loyalty programs aim to increase customer loyalty by rewarding customers for doing business with the firm. Through these programs, firms can potentially gain more repeat business and, at the same time, obtain rich consumer data that aid future CRM efforts. Since American Airlines launched the first contemporary loyalty program in 1981 , loyalty programs have blossomed and now span various industries, including retail, travel, and financial industries. It is estimated that more than half of U.S. adults are enrolled in at least one loyalty program (Kivetz and Simonson 2003).

Despite the prevalent use of loyalty programs, their effectiveness is not well understood (Bolton, Kannan, and Bramlett 2000). Some researchers question the value of loyalty programs. For example, Dowling (2002) suggests that loyalty programs do not necessarily foster loyalty and are not cost effective and that the proliferation of loyalty programs is a hype or a "me-too" scheme. Conversely, some recent studies show that loyalty programs have a positive impact on consumers' repatronage decisions and their share of wallet (e.g., Lewis 2004; Verhoef 2003). With limited empirical validations, the debate on whether loyalty programs are truly effective continues. The divergent views suggest a need to understand these programs better. This is also of strategic importance because such programs are costly investments and require a firm's long-term commitment. It is vital for managers to know whether and how these programs work before they take the plunge.

Although evidence about the effectiveness of loyalty programs has begun to accumulate recently, the field is still underdeveloped, and a clear picture has yet to emerge. Addressing this issue, Bolton, Kannan, and Bramlett (2000, p. 28) suggest that "to determine the 
long-term efficacy of a loyalty rewards program, a company must quantify the program's influence on future purchase behavior (e.g., usage levels)."

The key research question is whether loyalty programs change consumers' patronage levels and help the retail industry to retain its customers. This outcome is important to study because they are directly related to consumer profitability and the financial success of a loyalty program.

\section{Loyalty Programmes}

A "loyalty program" is defined as a program that allows consumers to accumulate free rewards when they make repeated purchases with a firm. Loyalty programs are often part and parcel of a comprehensive customer relationship strategy. As acquiring new customers is getting costlier day by day, business organizations have offered continuity/loyalty programmes to retain/reward existing customers and maintain relationships. Loyalty programs not only help build customer commitment but also demonstrate a firm's commitment. Loyalty Cards are an excellent marketing tool for rewarding current customers and attracting new ones. Loyalty cards and membership cards with personalized information add tremendous value to customer service and strengthen a company's brand recognition. The Loyalty card adds prestige to the card holder and confers benefits to him.

A loyalty card program is a marketing program that rewards customers with discounts and rebates for their repeated business, while providing sellers with information about the customer's purchasing patterns. Customers register and then are given a card that they present whenever they make a purchase. Both the seller and the consumer profit from these programs. Customers receive discounts or rebates and sellers receive information that enables them to offer their customers the products that they prefer. The program thus achieves the objectives of rewarding most frequent customers and ensuring repeat purchase. A win-win situation results with both buyer and issuer gaining. 


\section{Benefits of Loyalty Programmes}

\section{Benefits to Firm:}

- Loyalty cards leads to lower price sensitivity \& stronger store attitude which create switching barriers.

- Loyalty cards creates loyal customers who brings higher average sales due to cross selling \& up-selling opportunities

- Loyal customers are profitable asset for a company as; servicing existing customer is less costly compared to new one.

- Loyalty programmes also helps in increasing advocacy.

\section{Benefits to Consumers:}

- Consumers benefit, as some incentive is offered to stay loyal by the retail outlets.

- Customer will have satisfied sense of belonging as a customer becomes a part of loyal group.

- If the consumer is convinced about the value he derives from purchase he will go for repeated purchases and this reduces time in evaluation, comparison and search.

\section{Loyalty Programmes and Value Enhancement}

Loyalty programs are often considered value-sharing instruments and can enhance consumers' perceptions of what a firm has to offer (Bolton, Kannan, and Bramlett 2000; Yi and Jeon 2003). This value enhancement function is important because the ability to provide superior value is instrumental to customer relationship initiation and retention (Sirdeshmukh, Singh, and Sabol 2002; Woodruff 1997). Indeed, enhanced value perception is considered a necessary condition to a loyalty program's success (O'Brien and Jones 1995). Loyalty programs provide value to consumers in two stages. In the first stage, program points are issued to consumers at the time of purchase. Although these points have no practical value until they are redeemed, recent studies show that they have important psychological meaning to consumers (Hsee et al. 2003; Van Osselaer, Alba, and Manchanda 2004). The psychological benefit increases the 
transaction utility of a purchase (Thaler 1985) and, subsequently, the overall value perception of doing business with the firm. Because consumers can later redeem points for free rewards, point accumulation creates an anticipation of positive future events, which increases consumers' likelihood of staying in the relationship (Lemon, White, and Winer 2002). In the redemption stage, consumers receive both psychological and economic benefits from a loyalty program. The free reward functions as a positive reinforcement of consumers' purchase behavior and conditions them to continue doing business with the firm (Sheth and Parvatiyar 1995). Psychologically, giving free rewards to customers shows the firm's appreciation and personal recognition of its customers. This sense of being important can enhance consumers' overall sense of well-being and deepen their relationship with the firm (Bitner 1995; Gwinner, Gremler, and Bitner 1998). Some researchers suggest that there are other psychological benefits as well, such as the opportunity to indulge in guilt-free luxuries (Kivetz and Simonson 2002) and a sense of participation (Dowling and Uncles 1997), which may be especially appropriate for brands that do not carry this belongingness (Oliver 1999). All these psychological and economic benefits translate into an attractive value proposition from the firm.

\section{Loyalty Programmes and Relationship Commitment}

Beyond the need for superior value, a necessary condition for any relationship to develop is the commitment of both parties in the relationship (Morgan and Hunt 1994). Given a wide variety of choices and a low switching barrier, it is easy for today's consumers to switch among different firms. This poses significant threats to customer relationships because consumers are not likely to commit to a single brand or firm. Loyalty programs can alleviate this lack of commitment and reduce customer defection by raising switching costs. Because loyalty programs reward customers for their repeated patronage, consumers tend to focus their purchases in one program to maximize the benefits they receive (Sharp and Sharp 1997). Such vested interests in a program make it difficult for competitors to entice customers away from a firm. Using game-theoretic models, 
Kim, Shi, and Srinivasan (2001) demonstrate that such a competitive barrier benefits the firm and results in higher prices in the marketplace. This is especially true for highvariety- seeking products and services (Zhang, Krishna, and Dhar 2000). Loyalty programs not only help build customer commitment but also demonstrate a firm's commitment. It is often costly for firms to initiate and maintain a loyalty program. It requires extensive efforts to manage point records and reward issuance. After such a program is in place, it is usually difficult to terminate it without risking the loss of consumers' goodwill. Although a loyalty program brings real cost to the business, it also shows the firm's commitment to establishing a long-term relationship with its customers. Such a commitment and demonstration of goodwill can further deepen the relationship between the firm and its customers.

\section{Database for Loyalty Programmes:}

Data gathered through running loyalty schemes gives a true reflection of actions of consumers and allows in-depth analysis of customer rather than product or store. When loyalty cards are scanned at the point of purchase, data are captured automatically registering time, day, products bought, prices paid and variety of such information of a card consumer. Analysis of these datasets yield valuable insights into consumer shopping processes, reactions to marketing efforts and long term patterns of behaviors. It also reveals which customers deliver the bulk of revenue and/or profit by linking the purchase history to firm's cost data.

Data gathered through loyalty programmes can be put to use in the decision areas ranging from segmentation, corporate planning, store portfolio, brand management, merchandising, promotional and media activity, direct marketing, inventory management, pricing and store layout.

\section{Mega Mart Retail:}

Mega mart, a pioneer in the apparel value-retail segment, is today the largest value-retail chain in India, and offers its customers complete value-for-money through best of deals throughout the year with some of the top national and international apparel brands, all at fabulous 
deals. Mega mart was setup in 1996 as a venture of the prestigious Arvind Ltd. The chain currently has 183 company stores in 24 states $/ 110$ cities in India.

\section{Loyalty Programmes at Mega Mart:}

Loyalty programme of Mega Mart gives the Indian consumer of being rewarded every time he makes a purchase at any of the Mega Mart stores anywhere in the country. Consumers can make purchases at any store and accumulate points at a central level. These points are redeemable at any of Mega Mart stores. Members will earn loyalty bonus points, as and when introduced, for purchase of eligible products and services at store of Vishal Mega Mart. The loyalty card is valid only at Vishal Mega Mart (a unit of Vishal Retail Limited) only. The members can redeem the points only once the loyalty card has accumulated the balance of at least 50 points. The points accumulated shall be valid only for a period of 1 year only.

\section{Literature Review:}

The premise of Customer Relationship Management is that once a customer is locked in, it will be advantageous to both the organization as well as the customer to maintain relationships and would be a winwin situation for both. Consumers find it beneficial to join such programmes to earn rewards for staying loyal. Through loyalty programmes, firms can potentially gain more repeat business, get opportunity to cross-sell and obtain rich customer data for future CRM efforts. (Yuping Liu, 2007). Based on the realization that it is much less expensive for a business to retain its existing customers than it is to acquire new ones, most companies are adopting loyalty programs to retain their existing customer base. (Buttle, 2004). Satisfaction has often been perceived as the ultimate outcome of all activities carried out during the process of purchase and consumption. Satisfaction has always been described as processes and outcomes that have been identified as a key determinant for loyalty, particularly in the retail context. (Bloemer \& de Ruyter, 1998). There is increasing recognition that the ultimate objective of customer satisfaction measurements should be customer loyalty (Sivadas \& Baker-Prewitt, 2000; Sondoh Jr., Wan Omar, Abdul 
Wahid, Ismail, \& Harun, 2007). Extensive empirical evidence has noted that satisfaction is a major outcome of marketing activity and links the processes of decision-making and consumption with postpurchase phenomena such as attitude change, word-of-mouth, repeat purchase, purchase intention, and brand loyalty (Cronin \& Taylor, 1992; Oliver \& Swan, 1989). According to Keh and Lee (2006), loyalty programs are designed to enhance loyalty where their effectiveness and relevance become more evident when a certain level of satisfaction threshold is achieved. Consumers who are considered loyal do much more than merely continue to purchase from a particular firm. Loyalty is a primary goal of relationship marketing and is sometimes equated with the relationship-marketing concept itself (Sheth, 1996). A customer loyalty scheme is "a mechanism for identifying and rewarding loyal customers" (Rayers, 1996).

Lois O'Brien and Charles Jones (1995) posited that the rewards and loyalty programs are developed in such a manner that the customer needs and desires can be satisfied using cash value, choice of redemption options, aspiration value, relevance and convenience. Youjae Yi and Hoseond Leon (2003) concluded that effect of loyalty programme on customer loyalty is different on different customers depending on involvement. In high involvement conditions indirect rewards are considered more effective than the direct immediate rewards. While in the low involvement conditions, immediate rewards are more effective in building program's value than delayed rewards.

Singh \& Khan (2012) highlighted how short term actions with few modifications with the profit will turn into long term customer loyalty and hence long term benefit. The authors were focusing on understanding the customer retention and customer loyalty and their importance to the business. The authors also understand the approach of how to increase customer retention and customer loyalty towards the business. With the understanding of the behavior of the customers and satisfying them provides the benefit to the business in the long term. Establishing good relationship with the customers by providing 
impact of loyalty cards in initiating consumer purchasing preferences and repeat purchases, there is a need for an in depth research in this arena. Further research in this direction will help retailers in improving strategies to retain customers through loyalty card programme.

The current research examines the impact of loyalty card program initiated by Mega mart, on retaining its customers. It also aims to find out the customers' usage levels and their exclusive loyalty to the firm through the loyalty card programme.

\section{Objectives of the Study:}

- To study the impact of loyalty cards in retaining the customers.

- To study what initiated customers to go for loyalty cards

- To study whether loyalty cards will lead to repeat purchase by the customers.

- To understand the frequency of use of loyalty cards.

- To get an insight as to how customers view loyalty card programme.

\section{Research Methodology:}

Methodology has a prime importance in any study. The study was conducted with the help of structured questionnaire. The data was collected by conducting personal interview with the store manager and administering the questionnaire to the customers at the point of purchase. Data is derived by interviewing customers of Mega Mart retail outlet operating in M. G. Road, Mangalore.

\section{Sampling Design:}

Sampling unit taken for this study are the customers holding loyalty cards of Mega Mart Retail Outlet, Mangalore. The questionnaires were directly administered to the respondents. The Sample size for this study is 100 . Sampling units were taken by non-probability sampling technique (judgment sampling).

\section{Limitations of the Study:}

- Due to time and cost constraints the sample size of the study 
better services will create customer loyalty and more visits over time. This will bring more profit to the business in long-term and will reduce the competition. The study also identified the strategies which attract the customers to the retailer and also understood the considerations to be done while implementing them. With this, it will help the business to gain customer retention and loyalty towards their business if they implement them diligently. (Singh \& Khan 2012).

Agchi \& Xingbo (2011) identified a moderator, step-size ambiguity, and address that when ambiguity is high, only reward distance affects loyalty programs. When ambiguity is lower, consumers integrate step size with reward distance. The physical and psychological distance estimation contexts (e.g., weight loss, savings) where distances and step sizes can vary (e.g., as a function of units: kilograms vs. pounds), but especially in loyalty rewards contexts. (Bagchi \& Xingbo 2013).

Omar et al. (2009) pointed out that the introduction of customer relationship marketing instruments by retailers has been strongly increased in recent years both in theory and practice. Loyalty programs have become a popular choice of marketing strategy by retailers who believe that loyalty programs are an important strategy and mechanism for retailers to build store traffic, increase basket size and increase frequency by creating deeper relationship with their customer. However, some members in the marketing industry have begun to question the effectiveness of loyalty programs in obtaining customers' support and loyalty. The authors reported on the results of a preliminary study of the literature which has been conducted in an attempt to understand the issue and role of service quality in retail loyalty programs as well as factors that are important in loyalty program service quality.

East et al. (2005), defined Consumer loyalty as a singular concept, usually as an attitude toward the loyalty object or as repeat patronage behavior. The definition may combine attitude and behavior in either an additive or an interactive expression. The authors argue that definitions of loyalty are useful if they predict phenomena such as recommendation, search and retention (loyalty outcomes). The 
findings of the study addressed that in three consumer fields, the combination measures of customer loyalty often perform poorly as predictors of loyalty outcomes compared with singular measures since recommendation is predicted by attitude but not by repeat patronage. Retention and search behavior are predicted better by repeat patronage than by attitude. The prediction of loyalty outcomes is not improved by the inclusion of an interaction term in the model. The combination concepts ofloyalty are of limited value. And there is no form of loyalty that consistently predicts all the different loyalty outcomes and, so they abandon the idea of a general concept of loyalty.

Lewis (2004) developed a model for customers' response to a loyalty program under the assumption that purchases represent the choices of customers who are solving a dynamic optimization problem. This theoretical model is using a discrete-choice dynamic programming formulation. The author relies on specific loyalty program with data from an online merchant that specializes in grocery and drugstore items. The results suggest that the loyalty program under study is successful in increasing annual purchasing for a substantial proportion of customers. Loyalty programs have an important effect on customer relationship management for firms in travel related industries such as airlines, hotels, and rental cars. (Lewis, 2004)

\section{Need and importance of the study:}

Despite the prevalent use of loyalty programs, there is limited evidence on the long-term effects of such programs, and their effectiveness is not well established. Previous empirical studies conducted in this area provide mixed support for loyalty programs, and there is still much controversy over whether the loyalty program is an appealing marketing tool (Leenheer et al. 2003; Shugan 2005). Moreover, not all consumers respond to loyalty programs in the same way, because the appeal of a program can differ among consumers, depending on factors such as current usage levels and perception of effort advantage (Kim, Shi, and Srinivasan 2001; Kivetz and Simonson 2003). These individual differences may have contributed to the mixed findings in the literature. In order to understand the 
was limited to 100 .

- Study was limited to the Mega mart store located at M.G. Road, Mangalore.

- This study focuses only those customers who possess loyalty cards. To that extent it is a micro study.

\section{Data Interpretation}

Table No 01: Customer profile in terms of regularity of purchase

Number of responses: 100

\begin{tabular}{|l|c|c|}
\hline Options & Response & Percentage \\
\hline Regular & 65 & 65 \\
\hline Not regular & 35 & 35 \\
\hline
\end{tabular}

Source: Field survey

The above shows that 65 percent of the customers are regular in making their purchases at the Mega Mart and only 35 percent customers do not make purchases regularly.

Table No 02: Reasons for becoming the member of loyalty card programme

Number of responses: 132

\begin{tabular}{|l|c|c|}
\hline Options & Response & Percentage \\
\hline Quality of the product & 17 & 12.88 \\
\hline Friendly staff & 10 & 07.58 \\
\hline Convenience & 20 & 15.15 \\
\hline Range of brands & 40 & 30.30 \\
\hline Price & 12 & 09.09 \\
\hline Ambience & 01 & 00.76 \\
\hline Offers / discounts & 32 & 24.24 \\
\hline
\end{tabular}

Source: Field survey 
The above table indicates that around 30 percent of customers opt for loyalty card programme of Mega mart due to the wide range of brands that are available in the outlet closely followed by around 24 percent of customers opting due to the attractive offers and discounts offered by the store. Convenience and quality of the products rank next with 15 percent and 13 percent respectively. Findings suggest that ambience is negligible when it comes to being the member of the loyalty card programme.

Table No 03: Opinion towards the question whether loyalty card programme has resulted in increase in purchases

\begin{tabular}{|l|c|c|}
\hline Options & Response & Percentage \\
\hline Strongly agree & 11 & 11 \\
\hline Agree & 70 & 70 \\
\hline Disagree & 13 & 13 \\
\hline Strongly disagree & 06 & 06 \\
\hline
\end{tabular}

\section{Source: Field survey}

Survey results shows that 70 percent of the customers agree that loyalty card programme has resulted in an increase in their purchases from the outlet whereas 19 percent of the customers either disagree or strongly disagree.

Table No 04: Usage of loyalty cards while making purchases

Number of responses: 100

\begin{tabular}{|l|c|c|}
\hline Options & Response & Percentage \\
\hline Yes, all the time & 17 & 17 \\
\hline Most of the time & 34 & 34 \\
\hline Some of the time & 23 & 23 \\
\hline Rarely & 25 & 25 \\
\hline Never & 01 & 01 \\
\hline
\end{tabular}

Source: Field survey 
34 percent of the customers use loyalty cards most of the time and 25 percent customers use it rarely when making purchases. 23 percent use it occasionally whereas 17 percent of the customers use it all the time to make purchases. Only 1 percent of the customers never use their loyalty card while making their purchases.

Table No. 05: Opinion towards the Question whether loyalty cards have resulted in loyalty towards the retail outlet

Number of responses: 100

\begin{tabular}{|l|c|c|}
\hline Options & Response & Percentage \\
\hline Yes & 56 & 56 \\
\hline No & 47 & 47 \\
\hline
\end{tabular}

Source : Field survey

There is a divided opinion when it comes to finding out whether loyalty cards have resulted in loyalty towards the retail outlet. 56 percent of the customers interviewed opine that loyalty card programme has resulted in their becoming loyal to the outlet whereas 47 percent of the customers opine that the programme has not resulted in them being loyal towards the retail outlet.

Table No 06: Opinion towards the Question whether loyalty cards have resulted in initiating repeat purchases

Number of responses: 100

\begin{tabular}{|l|c|c|}
\hline Options & Response & Percentage \\
\hline Yes & 77 & 77 \\
\hline No & 23 & 23 \\
\hline
\end{tabular}

Source: Field survey

Of the customers interviewed, 77 percent agree that the loyalty card programme has resulted in their making repeated purchases at the said outlet, whereas 23 percent say that it has not resulted in repeat purchases. 
Table 07: Opinion towards the question whether the customers suggested the loyalty card programme to others

Number of responses: 100

\begin{tabular}{|l|c|c|}
\hline Options & Response & Percentage \\
\hline Yes & 37 & 37 \\
\hline No & 63 & 63 \\
\hline
\end{tabular}

Source: Field survey

Of the total respondents, 63 percent customers have not suggested that loyalty card programme to others whereas 37 percent have suggested it to others.

Table 08: The redemption rate of accumulated loyalty points

Number of responses: 100

\begin{tabular}{|l|c|c|}
\hline Options & Response & Percentage \\
\hline Yes & 14 & 14 \\
\hline No & 86 & 86 \\
\hline
\end{tabular}

Source: Field survey

Surprisingly, 86 percent of the customers have not redeemed their accumulated loyalty points and only 14 percent have redeemed them and availed the benefits of the programme.

Table 08 (a): The reasons for not opting redemption of accumulated loyalty points

Number of responses: 100

\begin{tabular}{|l|c|c|}
\hline Options & Response & Percentage \\
\hline $\begin{array}{l}\text { Not accumulated enough } \\
\text { points }\end{array}$ & 39 & 39 \\
\hline Not interested in rewards & 24 & 24 \\
\hline $\begin{array}{l}\text { Not aware of rewards } \\
\text { available }\end{array}$ & 23 & 23 \\
\hline
\end{tabular}

Source: Field survey 
The main reason for not redeeming the accumulated points is that the customers have not made enough purchases resulting in not accumulating sufficient points for redemption (39 percent). 24 percent of the customers are not interested in the rewards offered by the retail outlet and 23 percent of the respondents are not aware of the rewards that are available.

Table No 09: The reasons for company going in for loyalty card programmes

Number of responses: 100

\begin{tabular}{|l|c|c|}
\hline Options & Response & Percentage \\
\hline $\begin{array}{l}\text { Retailers genuinely wish to reward } \\
\text { customers for being loyal }\end{array}$ & 25 & 25 \\
\hline $\begin{array}{l}\text { It is a method to obtain details on } \\
\text { customers and their spending patterns }\end{array}$ & 21 & 21 \\
\hline It makes customers feel special & 48 & 48 \\
\hline Other(increase in sales) & 06 & 06 \\
\hline
\end{tabular}

Source: Field survey

48 percent of the customers feel that the reason a company goes for loyalty card programmes is that it makes customers feel special. 25 percent of them feel that retailers genuinely wish to reward customers for being loyal. 21 percent of them feel that it is a method to obtain details on customers and their spending patterns and 6 percent of them feel that the reason behind the loyalty card programme is increasing the sales.

From the Table No. 10, it can be seen that around 48 percent of the customers also visit other retail outlets to compare the offers and product ranges that are available. Loyalty card programme does not affect the purchase decision of 24 percent customers. Almost 19 percent of the customers prefer going to shops where they have loyalty cards and around 9 percent customers go only to those shops where he has a loyalty card. 
Table 10: The Effect of loyalty card programme on purchase behaviour

Number of responses: 108

\begin{tabular}{|l|c|c|}
\hline Options & Response & Percentage \\
\hline $\begin{array}{l}\text { Customer goes only to those shops } \\
\text { where he has a loyalty card }\end{array}$ & 10 & 09.26 \\
\hline $\begin{array}{l}\text { Customer prefers going to shops } \\
\text { where he has a loyalty card }\end{array}$ & 20 & 18.52 \\
\hline $\begin{array}{l}\text { Customer also visits other stores to } \\
\text { compare }\end{array}$ & 52 & 48.15 \\
\hline $\begin{array}{l}\text { Loyalty card does not impact his } \\
\text { purchase decision }\end{array}$ & 26 & 24.07 \\
\hline
\end{tabular}

Source : Field survey

Table No 11: The customer's opinion about the impact of loyalty card programme on loyalty towards the outlet

Number of responses: 100

\begin{tabular}{|l|c|c|}
\hline Options & Response & Percentage \\
\hline High impact & 17 & 17 \\
\hline Average impact & 48 & 48 \\
\hline Low impact & 14 & 14 \\
\hline No impact & 21 & 21 \\
\hline
\end{tabular}

Source : Field survey

48 percent of the customers feel that there is an average impact of loyalty card programme on their being loyal towards the outlet, whereas 21 percent feel that there is no impact. 17 percent of them feel that there is a high impact and only 14 percent feel that there is low impact of the programme on their loyalty to the store. 


\section{Customer profile:}

Table No.12: Age wise classification of Respondents

Number of responses: 100

\begin{tabular}{|l|c|c|}
\hline Options & Response & Percentage \\
\hline Below 18 & 08 & 08 \\
\hline $18-24$ & 29 & 29 \\
\hline $25-30$ & 31 & 31 \\
\hline $30-40$ & 13 & 13 \\
\hline $40-60$ & 11 & 11 \\
\hline 60 and above & 08 & 08 \\
\hline
\end{tabular}

\section{Source : Field survey}

8 percent of the respondents are below 18 years of age; 29 percent respondents belong to the age group of 18- 24 years; 31 percent belong to the age group of $25-30$ years; 13 percent of the respondents belong to the age group 30- 40 years; 11 percent belong to the age group 40-60 years and 8 percent of the respondents were above 60 years.

Table No 13: Gender wise classification of Respondents

Number of responses: 100

\begin{tabular}{|l|c|c|}
\hline Options & Response & Percentage \\
\hline Male & 54 & 54 \\
\hline Female & 46 & 46 \\
\hline
\end{tabular}

Source : Field survey

54 percent of the respondents are male and 46 percent of the respondents are female. 
Table No. 14: Employment status of Respondents

Number of responses: 100

\begin{tabular}{|l|c|c|}
\hline Options & Response & Percentage \\
\hline Full time & 48 & 48 \\
\hline Part-time & 13 & 13 \\
\hline Business & 08 & 08 \\
\hline Not employed & 31 & 31 \\
\hline
\end{tabular}

Source : Field survey

48 percent of the respondents interviewed were full- time employees; 13 percent were part- time employees; 8 percent were running their own business and 31 percent of the respondents were not employed.

Findings of the Study

The various findings of the study are as follows:

- The study brings out the fact that, 65 percent of the customers are regular in making their purchases at the Mega Mart. Around 30 percent of customers opt for loyalty card programme of Mega mart due to the wide range of brands that are available in the outlet closely followed by around 24 percent of customers opting due to the attractive offers and discounts offered by the store.

- The study indicates 70 percent of the customers agree that loyalty card programme has resulted in an increase in their purchases from the outlet.

- It is observed that, 34 percent of the customers use loyalty cards most of the time while making their purchases.

- More than 50 percent of the customers (56 percent) interviewed opine that loyalty card programme has resulted in their becoming loyal to the outlet whereas 47 percent of the customers opine that the programme has not resulted in them being loyal towards the retail outlet.

- The customers agree that the loyalty card programme has 
resulted in their making repeated purchases account for 77 percent.

- Out the respondents surveyed, 37 percent of the customers suggested the loyalty card programme to others.

- Major share of the customers have not redeemed their accumulated loyalty points( 86 percent) and only 14 percent have redeemed them and availed the benefits of the programme. 39 percent of the customers highlighted that the main reason for not redeeming the accumulated points is that the customers have not made enough purchases resulting in not accumulating sufficient points for redemption.

- The customers who feel that the reason a company goes for loyalty card programmes is that it makes customers feel special is 48 percent and 25 percent of them feel that retailers genuinely wish to reward customers for being loyal.

- The customers visit other retail value chain outlets also to compare the offers and product ranges that are available their percentage is 48 .

- The study indicates that, 48 percent of the customers feel that there is an average impact of loyalty card programme on their being loyal towards the outlet and 29 percent respondents belong to the age group of 18- 24 years. This indicates that the most of the customers who usually come and purchase at Mega Mart are middle aged or the youth.

\section{Suggestions}

- The points needed to be accumulated for redemption must be reduced in order to retain customers.

- Majority of customers who are the members of loyalty card program belong to the age group of 26-30 years. This indicates that even though the young crowd shop at Mega Mart, they are not keen in becoming the members of the loyalty programme. This reflects the lack of loyalty among the youths. On the other hand people above 30 years of age also do not subscribe to the loyalty card programme. This 
segment which earns the real income needs to be encouraged to join such programmes. This calls for imparting knowledge about such programmes through vigorous advertisements.

- The study also reflects the fact that loyalty card programmes have an average impact on the purchasing behaviour of the customers. It shows that there is a 'temporary' loyalty towards the outlet. To strengthen the loyalty attribute of the customer, the retail outlet should develop other promotional strategies in addition to loyalty card programme. In isolation, loyalty card programme may fail to create the much needed impact.

- This study points out to the fact that there is lack of 'good word-of-mouth' advertising on the part of the customers holding loyalty card. A startling 63 percent of the customers did not suggest others to go for these programs. The reasons are lack of awareness and the need for high redemption points. Thus, there is a need to educate customers since retail outlet strive on word-of-mouth advertising.

\section{Conclusion}

Loyalty card programme should not be the only retention strategy that should be adopted by the retail outlet in this changing vibrant environment. Mega Mart should think of proactive and innovative strategies in addition to loyalty card program. Mega Mart must keep looking for new and initiative tools to differentiate their loyalty programs, to attract new customers and to increase the purchasing amount of the existing ones.

\section{References}

Agchi, R., \&Xingbo , L, (2011), Illusionary Progress in Loyalty Programs: Magnitudes, Reward Distances, and Step-Size Ambiguity. Journal of Consumer Research, Vol. 37 February 2011, P 184-179.

Bolton, R. N., Kannan, P. K., \& Bramlett, M. (2000). Implications of loyalty program membership and service experiences for customer retention and value. Journal of Academy of Marketing Science, 28(Winter), 95-108.

Bloemer, J., \& de Ruyter, K. (1998). Investigating drivers of bank loyalty: 
The complex relationship between image, service quality. International Journal Bank Marketing, 16(6/7), 276-286.

Buttle, F. (2004). Customer relationship management: Concepts and tools. UK: Elsevier Butterworth-Heinemann.

Cronin, J. J., \& Taylor, S. A. (1992). Measuring service quality: A reexamination and extension. Journal of Marketing, 56(July), 55-68.

Dowling, G. R., \& Uncles, M. (1997). Do customer loyalty programs really work? Sloan Management Review, 38(4), 71-82.

Oliver, R. L. (1999). Whence consumer loyalty. Journal of Marketing, 63, 33-44.

Omar, N. A., Azrin, M., \& Sarah, H,( 2009) " What Customers Really Want: Exploring Service Quality Dimensions in a Retail Loyalty Program”. Unitar E- Journal, Vol.5, No.1 (January) 2009.

Sheth, J. N. (1996). Organizational buying behavior: Past performance and future expectations. Journal of Business \& Industrial Marketing, 11(3/4), 7-24.

Sivadas, E., \& Baker-Prewitt, J. L. (2000). An examination of the relationship between service quality, customer satisfaction, and store loyalty. International Journal of Retail and Distribution Management, 28(2), 73-78.

Yuping Liu, (2007) "The Long-Term Impact of Loyalty Programs on Consumer Purchase Behaviour and Loyalty" Journal of Marketing, Vol.71, (October), 19-35.

Yi, Y., \& Jeon, H. (2003). Effects of loyalty programs on value perception, program loyalty and brand loyalty. Journal of the Academy of Marketing Science, 31(3), 229-240. 